\title{
Bilateral extensive corticospinal tract lesions in MOG antibody-associated disease
}

Vincenzo Mastrangelo, MD, Gian Maria Asioli, MD, Matteo Foschi, MD, Marina Padroni, MD, Lucia Pavolucci, MD, Patrizia Cenni, MD, and Pietro Querzani, MD

Neurology ${ }^{\circledR}$ 2020;95:648-649. doi:10.1212/WNL.0000000000010662

Figure 1 Brain and spinal cord MRI at presentation
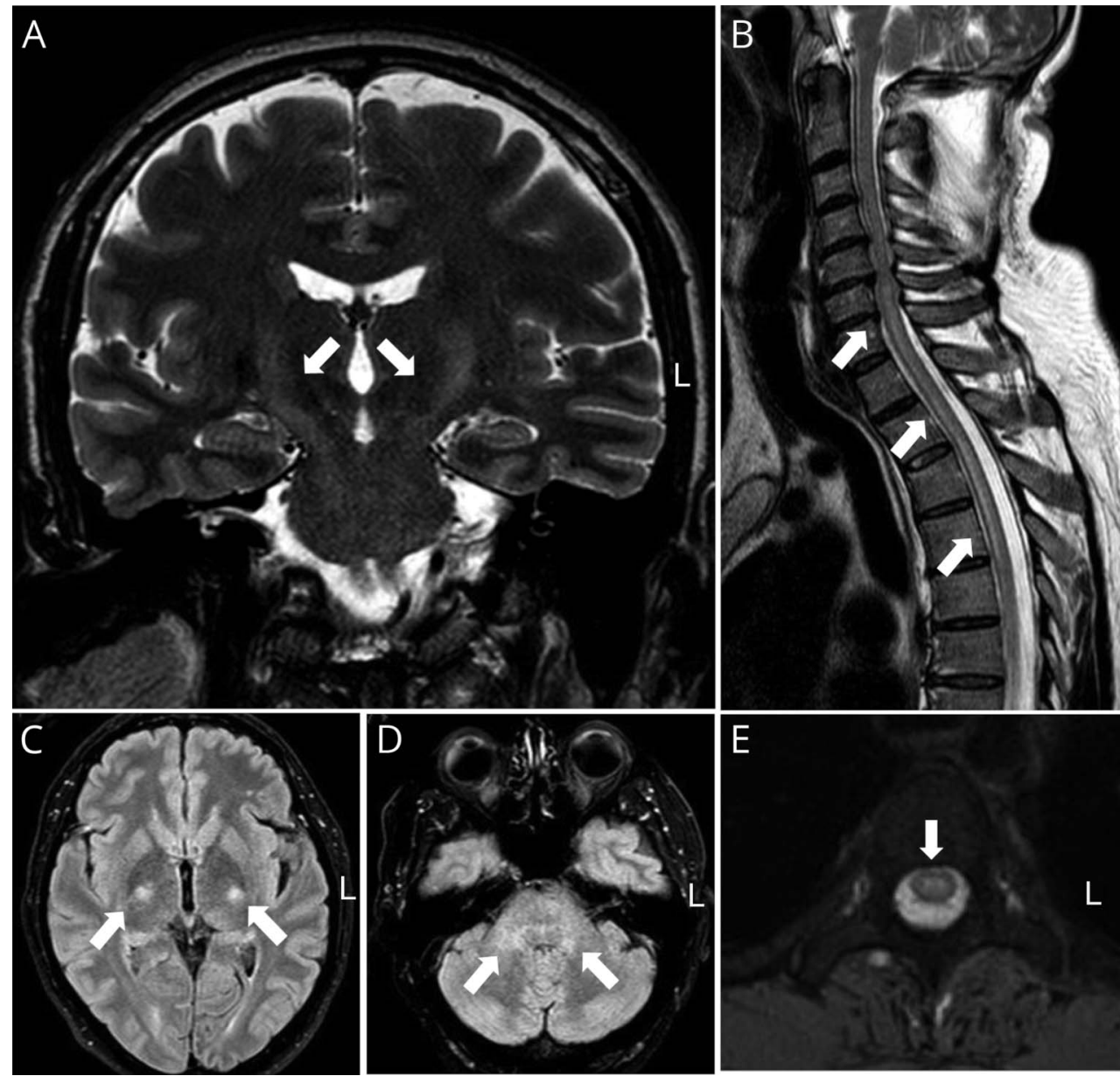

T2 sequences show bilateral hyperintensity of corticospinal tracts, extending from the internal capsule to pons (A), and a longitudinally extendend hyperintese lesion of the spinal cord (B). Axial fluid-attenuated inversion recovery (FLAIR) sequences document bilateral lesions of corticospinal tracts (C) and middle cerebellar peduncles (D). Axial T2fast field echo (T2-FFE) slice shows involvement of the central portion of the spinal cord (E, T3 level).

A healthy 53-year-old man developed acute flaccid paraplegia, spinal sensory level, and urinary retention. Examination revealed bilateral pronator drift. MRI demonstrated demyelinating non-enhancing lesions involving corticospinal tracts (CSTs), middle cerebellar peduncles, and spinal cord (figure 1). CSF analysis disclosed lymphocytic pleocytosis and mildly elevated protein.

\author{
Correspondence \\ Dr. Mastrangelo \\ vincenzo.mastrangel2@ \\ studio.unibo.it
}


Figure 2 Brain and spinal cord MRI after treatment

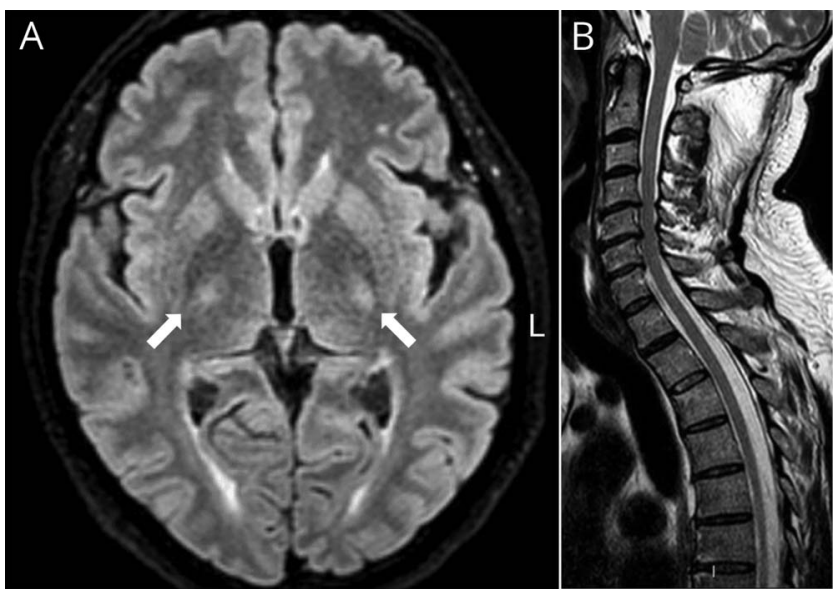

Follow-up brain and spinal cord MRI after 24 days shows reduction of corticospinal tract hyperintensity in axial fluid-attenuated inversion recovery images (A); spinal cord MRI demonstrates resolution of cord lesion in sagittal T2 sequences $(B)$

Euroimmun fixed cell-based assay for serum anti-myelin oligodendrocyte glycoprotein (MOG) and anti-aquaporin-4 (AQP4) antibodies showed low positivity for MOG immunoglobulin G (IgG) (1:10). Treatment with high-dose glucocorticoids and IV immunoglobulin was effective (figure 2). Long CST lesions were found in anti-AQP4 IgG-seropositive neuromyelitis optica spectrum disorders. ${ }^{1}$ Bilateral extensive lesions following CST are a novel finding in MOG-related CNS autoimmunity. ${ }^{2}$

\section{Study funding}

No targeted funding reported.

\section{Disclosure}

The authors report no disclosures relevant to the manuscript. Go to Neurology.org/N for full disclosures.
Appendix Authors

\begin{tabular}{|c|c|c|}
\hline Name & Location & Contribution \\
\hline $\begin{array}{l}\text { Vincenzo } \\
\text { Mastrangelo, } \\
\text { MD }\end{array}$ & $\begin{array}{l}\text { Department of Biomedical } \\
\text { and Neuromotor Sciences, } \\
\text { University of Bologna, Italy }\end{array}$ & $\begin{array}{l}\text { Designed and } \\
\text { conceptualized study, } \\
\text { analyzed the data, } \\
\text { drafted the } \\
\text { manuscript }\end{array}$ \\
\hline $\begin{array}{l}\text { Gian Maria } \\
\text { Asioli, MD }\end{array}$ & $\begin{array}{l}\text { Department of Biomedical } \\
\text { and Neuromotor } \\
\text { Sciences, University of } \\
\text { Bologna, Italy }\end{array}$ & $\begin{array}{l}\text { Acquisition of data, } \\
\text { drafted the manuscript }\end{array}$ \\
\hline $\begin{array}{l}\text { Matteo } \\
\text { Foschi, MD }\end{array}$ & $\begin{array}{l}\text { Neurology Unit, S. Maria } \\
\text { delle Croci Hospital-AUSL } \\
\text { Romagna, Ambito Di } \\
\text { Ravenna, Italy }\end{array}$ & $\begin{array}{l}\text { Revised the manuscript } \\
\text { for intellectual content }\end{array}$ \\
\hline $\begin{array}{l}\text { Marina } \\
\text { Padroni, MD }\end{array}$ & $\begin{array}{l}\text { Neurology Unit, S. Maria } \\
\text { delle Croci Hospital-AUSL } \\
\text { Romagna, Ambito Di } \\
\text { Ravenna, Italy }\end{array}$ & Acquisition of data \\
\hline $\begin{array}{l}\text { Lucia } \\
\text { Pavolucci, } \\
\text { MD }\end{array}$ & $\begin{array}{l}\text { Neurology Unit, S. Maria } \\
\text { delle Croci Hospital-AUSL } \\
\text { Romagna, Ambito Di } \\
\text { Ravenna, Italy }\end{array}$ & Acquisition of data \\
\hline $\begin{array}{l}\text { Patrizia } \\
\text { Cenni, MD }\end{array}$ & $\begin{array}{l}\text { Neuroradiology, S. Maria } \\
\text { delle Croci Hospital-AUSL } \\
\text { Romagna, Italy }\end{array}$ & $\begin{array}{l}\text { Acquisition of data, } \\
\text { revised the manuscript } \\
\text { for intellectual } \\
\text { content }\end{array}$ \\
\hline $\begin{array}{l}\text { Pietro } \\
\text { Querzani, MD }\end{array}$ & $\begin{array}{l}\text { Neurology Unit, S. Maria } \\
\text { delle Croci Hospital-AUSL } \\
\text { Romagna, Ambito Di } \\
\text { Ravenna, Italy }\end{array}$ & $\begin{array}{l}\text { Revised the manuscript } \\
\text { for intellectual content }\end{array}$ \\
\hline
\end{tabular}

\section{References}

1. Kim HJ, Paul F, Lana-Peixoto MA, et al. MRI characteristics of neuromyelitis optica spectrum disorder: an international update. Neurology 2015;84: $1165-1173$.

2. Denève $M$, Biotti $D$, Patsoura $S$, et al. MRI features of demyelinating disease associated with anti-MOG antibodies in adults. J Neuroradiol 2019;46: 312-318.

\section{Neurology $y^{\circledR}$ Online CME Program}

Earn CME while reading Neurology. This program is available only to online Neurology subscribers. Read the articles marked CME, go to Neurology.org, and click on CME. This will provide all of the information necessary to get started. The American Academy of Neurology (AAN) is accredited by the Accreditation Council for Continuing Medical Education (ACCME) to sponsor continuing medical education for physicians. Neurology is planned and produced in accordance with the ACCME Essentials. For more information, contact AAN Member Services at 800-879-1960. 


\section{Neurology}

Bilateral extensive corticospinal tract lesions in MOG antibody-associated disease

Vincenzo Mastrangelo, Gian Maria Asioli, Matteo Foschi, et al.

Neurology 2020;95;648-649 Published Online before print August 14, 2020

DOI 10.1212/WNL.0000000000010662

This information is current as of August 14, 2020

$\begin{array}{ll}\begin{array}{l}\text { Updated Information \& } \\ \text { Services }\end{array} & \begin{array}{l}\text { including high resolution figures, can be found at: } \\ \text { http://n.neurology.org/content/95/14/648.full }\end{array} \\ \text { References } & \text { This article cites } 2 \text { articles, } 1 \text { of which you can access for free at: } \\ & \text { http://n.neurology.org/content/95/14/648.full\#ref-list-1 } \\ \text { Subspecialty Collections } & \text { This article, along with others on similar topics, appears in the } \\ & \text { following collection(s): } \\ & \text { All Demyelinating disease (CNS) } \\ & \text { http://n.neurology.org/cgi/collection/all_demyelinating_disease_cns } \\ & \text { MRI } \\ & \text { http://n.neurology.org/cgi/collection/mri } \\ & \text { Transverse myelitis } \\ & \text { http://n.neurology.org/cgi/collection/transverse_myelitis } \\ & \text { Information about reproducing this article in parts (figures,tables) or in } \\ & \text { its entirety can be found online at: } \\ & \text { http://www.neurology.org/about/about_the_journal\#permissions } \\ \text { Permissions \& Licensing } & \text { Information about ordering reprints can be found online: } \\ & \text { http://n.neurology.org/subscribers/advertise }\end{array}$

Neurology ${ }^{\circledR}$ is the official journal of the American Academy of Neurology. Published continuously since 1951, it is now a weekly with 48 issues per year. Copyright () 2020 American Academy of Neurology. All rights reserved. Print ISSN: 0028-3878. Online ISSN: 1526-632X.

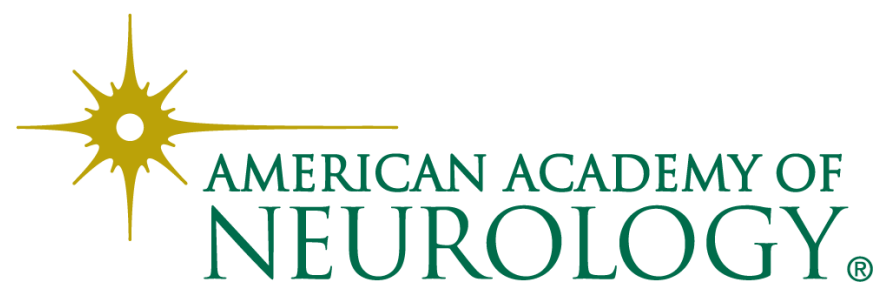

